\title{
UPACARA ADAT GAWAI DALAM MEMBENTUK NILAI-NILAI SOLIDARITAS PADA MASYARAKAT SUKU DAYAK KALIMANTAN BARAT
}

\author{
Irmalini Syafrita $\left({ }^{1 *}\right)$, Mukhamad Murdiono $\left({ }^{2}\right)$ \\ 12 Department of Civic Education, Graduate School of Universitas Negeri Yogyakarta, Indonesia
}

\begin{tabular}{|c|c|}
\hline \multicolumn{2}{|c|}{ ARTICLE INFORMATION } \\
\hline $\begin{array}{l}\text { Submitted } \\
\text { Review } \\
\text { Accepted } \\
\text { Published } \\
\text { Available O }\end{array}$ & $\begin{array}{l}: 16^{\text {th }} \text { September, } 2019 \\
: 31^{\text {st }} \text { October, } 2020 \\
: 15^{\text {th }} \text { November, } 2020 \\
: 15^{\text {th }} \text { December } 2020 \\
: \text { December } 2020\end{array}$ \\
\hline KEYWORD & \\
\hline
\end{tabular}

Budaya; Gawai; Dayak; Solidaritas

\section{CORRESPONDENCE}

E-mail: irmalinisyafrita@gmail.com

\begin{abstract}
A B S T R A C T
The purpose of writing this article is to determine the Gawai culture in shaping the values of solidarity among the Dayak tribal communities in West Kalimantan. This article was prepared using the library research method, namely the method of collecting data by utilizing literature sources and materials. The result of the conclusion is that Gawai is a traditional Dayak ceremony which has become a tradition to this day. The Dayak gawai is one of the traditional ceremonies which is still actively carried out by the Dayak people. The Gawai Dayak traditional ceremony is one of the sources of local history in West Kalimantan. The implementation of the traditional Gawai ceremony aims to ask for safety and gratitude to God for the harvest which is usually done every one year. The traditional Gawai ceremony is held after the main harvest and ends with the traditional ritual of Rising Dango and reciting incantations and prayers or commonly known as Matik which aims to ask for blessings to God or Jubata. The implementation of the traditional gawai ceremony requires the involvement of all Dayak tribal communities to be able to work together in the preparation and implementation. Therefore, gadgets become the media needed to renew the spirit and sense of solidarity between Dayak tribal communities in West Kalimantan. The Gawai Traditional Ceremony is one of the very sacred religious rituals for the Dayak Tribe, therefore the Gawai Traditional ceremony only involves the Dayak Tribe. However, as the times progressed, the government tried to preserve the traditional Gawai ceremony, so that it became a routine tourism agenda in Pontianak City every year.
\end{abstract}

\section{A. PENDAHULUAN}

ndonesia merupakan salah satu Negara dengan berbagai macam agama, adat istiadat, suku, etnik dan keadaan geografis yang beraneka ragam. Kebudayaan pada setiap daerah di Indonesia pada umumnya memiliki perbedaan, sehingga memunculkan identitas dan ciri khas pada masing-masing daerah, yang berupaya untuk mempertahankan eksistensi budayanya. Dengan berbagai macam kebudayaan yang ada, Indonesia dengan kata lain merupakan sebagai Negara multikultural. Menurut pendapat Grant, C.A (2018:5) multikultural merupakan aktivitas sosial yang memiliki identitas beragam. Aktivitas dianggap sangat penting karena dapat mewujud kan keanekaragaman di dalam suatu bangsa, yang menjadi identitas diri khususnya Indonesia. Sehingga dapat menumbuhkan rasa saling menghormati dengan berbagai perbedaan sosial dengan latar belakang budaya yang berbeda. Aktivitas multikultural dapat mendorong kerjasama dalam cakupan antar kelompok, sehingga perbedaan antar kelompok dapat dihilangkan dan menciptakan kehidupan masyara kat yang beranekaragam.

Indonesia merupakan Negara kesatuan yang memiliki keanekaragaman corak budaya yang menjadi identitas jati diri bangsa Indonesia. Sebagai Negara yang memiliki keanekaragaman, arus globalisasi pada saat ini menjadi tantangan tersendiri bagi masyarakat Indonesia, yang dapat berdampak pada perubahan yang terjadi pada tatanan kehidupan masyarakat. Khususnya tatanan hubungan yang semakin terbuka dan bebas, sehingga berkurangnya rasa cinta terhadap budaya dan tradisi lokal. Hal ini tentunya menjadi salah satu ancaman yang dapat mempengaruhi 
jati diri masyarakat Indonesia yang memiliki suku, adat dan budaya.

Berkembangnya budaya luar yang dianggap lebih praktis dan nyaman dalam kehidupan masyarakat dianggap sebagai modernisasi. Namun hal tersebut akan berdampak negatif apabila masyarakat tidak mengimbangi dan memfilter, sehingga hal tersebut dapat menyebabkan culture lag. Menurut pendapat Setiadi dan Kolip (2011:143) Culture Lag merupakan suatu keadaan budaya yang tertinggal oleh perkembangan sosio kultur, dimana masyarakat belum memiliki kesiapan sikap dan mental dalam menerima dan mengikuti perubahan yang ada. Hal ini selaras dengan pendapat Hatu (2011:5) yang mengartikan culture lag sebagai suatu keadaan atau kondisi yang terjadi apabila unsur-unsur kehidupan masyarakat tertinggal jauh dengan berbagai pembangunan sarana yang berkembang secara pesat sehingga perlu adanya penyesuaian terhadap perubahan yang ada.

Oleh sebab itu akibat yang berdampak pada terkikisnya adat istiadat sedikit demi sedikit hingga mengikis jati diri yang dimiliki masyarakat adat, suku, budaya yang ada di Indonesia. Sehingga Indonesia tentunya perlu memperkokoh dan memperkuat pondasi pada masyarakat modern. Hal ini guna untuk memperkuat identitas dengan cara melestarikan kebudayaan yang dimiliki, tentunya sesuai dengan identitas Indonesia sebagai Negara yang kaya akan keanekaragaman suku dan budaya. Untuk itu sangat penting bagi masyarakat Indonesia untuk memiliki identitas sebagai bangsa yang berbudaya, memperta hankan nilai-nilai luhur dan kearifan lokal yang merupakan tradisi warisan budaya yang harus dijaga sampai kapanpun.

Tradisi merupakan tatanan pemahaman dan kepercayaan akan nilai, sikap yang didapat dari sebagian besar orang dari generasi ke generasi melalui individu dan kelompok masyarakat. Menurut pendapat Vitanyi, I (2015:253) tradisi merupakan segala sesuatu yang besifat manusiawi, yang dipandang sebagai suatu proses berkembangnya pengetahuan dan budaya. Oleh sebab itu tradisi diterapkan secara turun menurun, karena dianggap sebagai dasar dan pondasi dikehidupan mayarakat tersebut. Tradisi menjadi unsur terpenting bagi kebudayaan guna untuk menciptakan nilai etik dan etetika, rasa solidaritas antar sesama serta nilai-nilai sosial lainnya pada masyarakat, sehingga terbentuk keseimbangan antara nilai material dan nilai spiritual di dalam kehidupan masyarakat.

Nilai-nilai tersebut perlu diperhatikan dan dikembangkan guna tidak terjadi ketimpangan sehingga tetap terjaga dan bertahan hingga masa yang akan datang, guna menciptakan kemak muran dalam kehidupan masyarakat. Banyak pengaruh yang diciptakan dari kebiasaankebiasaan yang dilakukan masyarakat, melalui tradisi yang biasa dilakukan secara rutin. Untuk itu tradisi mempengaruhi disetiap aspek kehidupan masyarakat untuk saling terkait antara satu dengan lainnya. Menurut pendapat Dadang Supardan (2013:207) tradisi merupakan pola tingkah laku yang dipercayai masyarakat dan menjadi bagian dari suatu kebudayaan dan dilakukan secara turun temurun. Oleh karena itu, menurut Dadang Suparlan segala sesuatu yang sudah menjadi kebiasaan suatu masyarakat dan diikuti dari generasi ke generasi dari segala aspek kehidupannya, maka hal tersebut dapat diartikan sebagai tradisi.

Salah satu tradisi yang ada di Nusantara diantaranya ialah Gawai, yang berasal dari Kalimantan. Kalimantan merupakan salah satu pulau terbesar di Indonesia dengan berbagai macam kebudayaan yang ada. Gawai merupakan tradisi masyarakat suku Dayak Kalimantan. Kebudayaan Gawai merupakan salah satu dari berbagai macam kebudayaan dan tradisi, adat istiadat dan ritual yang erat kaitannya dengan kehidupan masyarakat suku Dayak Kalimantan. Gawai biasa dilakukan suku Dayak untuk mengungkapkan rasa syukur kepadaTuhan. Menurut pendapat Herman Ivo (2002:292) gawai merupakan satu-satunya tradisi di dalam kebudayaan suku Dayak yang rutin dilaksanakan setiap tahunnya di kota Pontianak, Kalimantan Barat.

Gawai dapat diartikan sebagai pembacaan mantera (nyanghathn) yang ditampilkan dalam bentuk budaya tradisional. Upacara yang dilaksanakan merupakan bentuk wujud dari rasa syukur kepada Jubata. Jubata merupakan pencipta dan pemelihara segala sesuatu yang ada di alam nyata ataupun dialam maya. Oleh karena itu bagi masyarakat suku Dayak, Jubata sangat dihormati, dimuliakan serta dianggungkan. Sebab itu mereka percaya segala sesuatu yang ada di alam ini berasal dari Jubata, seperti salah satunya ialah hasil panen raya. Upacara tersebut rutin dilaksanakan masyarakat Dayak Kalimantan Barat setiap tahunnya dimasa panen raya. Upacara panen raya bagi suku Dayak juga dikenal dengan berbagai nama, orang Dayak Hulu menamai dengan Gawai, di Kabupaten Sambas dan Bang kayang biasa dikenal dengan sebutan Maka'Dio, sedangkan orang Dayak Kayaan, dikampung Mendalam Kabupaten Putus Sibau biasa menyebut dengan sebutan dengan Denge. Pelaksanaan Gawai biasanya memakan waktu hingga tiga bulan yakni, April hingga Juni, oleh karena itu pelaksanaan Gawai di Kalimantan Barat biasa dilakukan pada tanggal 20 Mei setiap tahunnya. Gawai berperan penting bagi masyarakat suku Dayak guna mengungkapkan rasa syukur. Selain itu Gawai pada masyarakat suku Dayak juga berguna untuk menjaga dan menciptakan rasa solidaritas antar sesama. Keterlibatan seluruh masyarakat pada kegiatan Gawai ini tentunya memerlukan kerjasama antar 
individu, sehingga dapat membentuk rasa solidaritas antar individu pada suku Dayak.

Menurut pendapat Siebold, A. (2017:872) solidaritas merupakan rasa persamaan antar individu di dalam suatu kelompok yang terjaga secara harmomis. Sehingga menimbulkan rasa persaudaraan dan pertemanan yang didasari oleh rasa peduli dan kekeluargaan, yang terjalin secara kompak di dalam suatu lingkungan ataupun kelompok. Sedangkan menurut pendapat Tormos, F (2017:9) solidaritas juga diartikan sebagai keadilan. Menurut Tormos solidaritas akan terbentuk ketika individu membentuk sebuah kelompok ataupun komunitas dengan gerakan sosial, bergabung secara bersama dalam menggapai suatu tujuan.

Jadi dapat disimpulkan bahwa solidaritas merupakan perasaan yang di dasari rasa saling percaya antara individu satu dengan yang lainnya, yang terbentuk dalam satu kelompok ataupun komunitas. Rasa saling percaya yang terikat oleh perasaan emosional dan moral mendasari terjalinnya rasa saling hormat menghormati, rasa kekeluargaan, dan pertemanan terhadap sesama sehingga dapat bekerjasama dalam menggapai tujuan dan membentuk ikatan sosial

Ikatan sosial perlu di tingkatkan guna mempertahankan rasa solidaritas antar sesama, mengingat pada saat ini solidaritas mulai tergantikan oleh solidaritas organic. Suatu keadaan dimana mana setiap individu yang terikat akan suatu kepentingan satu dengan lainnya, sehingga setiap individu hanya menjalankan peran masing-masing tanpa didasari kesadaran kolektif. Oleh karena itu perlu adanya suatu kondisi yang dapat meningkatkan kesadaran individu akan pentingnya kebersamaan dalam kehidupan secara berdampingan. Hal tersebut dapat dilakukan dengan mengadakan kegiatan bersama seperti acara yang bersifat kesukuan, keagamaan dan lain-lain, sehingga ikatan solidaritas tetap terjaga.

Oleh karena itu Gawai merupakan salah satu kegiatan adat yang hadir ditengah-tengah kehidupan masyarakat sejak lama perlu dipertahankan, hal ini dikarenakan Gawai memiliki peran dalam mempertahankan rasa solidaritas antar individu terutama pada suku Dayak. Modernisasi yang begitu pesat, banyak pergeseran terjadi di dalam kehidupn tetutama suku dayak. Salah satu diantaranya ialah Rumah panjang, pada saat ini rumah panjang sangat sulit untuk ditemui. Hal tersebut dianggap sebagai hambatan dalam pembangunan di Kalimantan oleh pemerintah. Oleh karena itu kegiatan Gawai sangat penting dan perlu dilestarikan dalam mempertahankan adat budaya serta rasa solidaritas antar sesama melalui kerjasama antar individu dalam persiapan maupun pelaksaan Gawai.

Dari pemasalah tersebut tentu saja hal ini menjadi salah satu faktor yang dapat menghan curkan sendi sendi suku Dayak terutama pada aspek solidaritas. Oleh sebab itu norma-norma maupun adat istiadat dan tradisi sangat berperan penting dalam menopang solidaritas sosial masyarakat suku Dayak. Selain itu guna mempertahankan solidaritas sosial yang sudah ada sejak dulu yang menjadi bagian dari kehidupan masyarakat suku Dayak itu sendiri. Hal ini dikarenakan Gawai dayak sendiri memiliki peran besar dalam menyumbangkan nilai-nilai penting dalam kehidupan sosial suku Dayak. Upacara tradisi Gawai Dayak merupakan salah satu upacara tradisi yang sampai sekarang masih terus aktif dilakukan oleh masyarakat suku Dayak. Upacara tradisi Gawai Dayak merupakan salah satu sumber sejarah lokal yang ada di daerah Kalimantan Barat. Tradisi Gawai Dayak sudah berlangsung sejak lama dan masih dipertahankan hingga saat ini.

Masyarakat suku Dayak merupakan masyarakat Agraris yang sangat menghormati dan menjunjung tinggi nilai-nilai luhur nenek moyang mereka, baik nilai religius, sosial dan komunal. Oleh karena itu menurut Puewanto dan Soedjito (2009:21) bahwa nilai-nilai tersebut dapat berpengaruh terhadap system sosial dan budaya, tidak terkecuali pada pelaksanaan tradisi dan adat istiadat yang sudah menjadi kebiasaan pada masyarakat. Oleh karena itu, Gawai yang terdapat di dalam masyarakat suku Dayak sangat berperan dalam kehidupan masyarakat suku Dayak, Gawai merupakan sumber inspirasi bagi masyarakat untuk dapat menata kehidupan secara bersama. Hal ini dikarenakan di dalam kehidupan suku Dayak, Gawai menjadi tolok ukur dalam menentukan sikap dan tata karma, sopan santun setiap masyarakat pada suku Dayak. Kerjasama yang terjalin antar masyarakat dapat mempererat rasa solidaritas, sehingga pesan moral yang terda pat di dalam upacara Gawai dapat mempengaruhi segala aspek kehidupan masyarakat, terutama dalam membangun solidaritas antar sesama masyarakat suku Dayak baik dalam bentuk perbuatan maupun fikiran.

Maka dari itu penulisan artikel ini bertujuan untuk memerkenalkan budaya Gawai sebagai salah satu upacara adat salah satu suku di Indonesia yaitu suku Dayak. Sebagai kegiatan tahunan yang telah dilaksanakan setiap tahunnya sebagai salah satu bukti bahwa solidaritas pada suku Dayak masih terjaga selama bertahun-tahun.

\section{B. METODE PENELITIAN}

$\mathrm{P}$ enulisan artikel ini dilakukan dengan menggunakan metode kajian pustaka. Metode kajian pustaka merupakan metode pengumpulan data dengan cara menelaah dari berbagai literatur, catatan dan laporan-laporan serta sumber-sumber kepustakaan lainnya yang berhubungan dengan masalah yang terkait (Nazir, 2013:93). Metode kajian pustaka memanfaatkan 
sumber dan bahan kepustakaan seperti buku, artikel serta hasil penelitian ilmiah yang terkait dengan upacara adat Gawai dalam membentuk nilai-nilai solidaritas pada masyarakat suku dayak Kalimantan Barat. Setelah mendapat beberapa referensi terkait tema penelitian, bahan dibaca bagian poin-poin penting yang berhubungan dengan tema, lalu mengutip informasi, menga nalisis kemudian merangkum. Rangkuman selesai, kemudian tulisan digeneralisasikan dengan kajian teori yang relevan sehingga membentuk satu tulisan hasil penelitian yang utuh.

\section{HASIL DAN PEMBAHASAN 1. Suku Dayak}

$\mathrm{P}$ ulau Kalimantan merupakan salah satu pulau besar yang berada di Indonesia. Pulau Kalimantan terbagi dari beberapa provinsi yang terdiri dari beranekaragam suku, budaya, adat istiadat dan tradisi yang masih berperan penting di dalam kehidupan masyarakat sehari-harinya. Dari beragai ragam suku yang ada, suku Dayak menjadi salah satu suku yang mendiami pulau Kalimantan khususnya di Kalimantan Barat. Dayak atau Daya merupakan etnis Austronesia yang dianggap sebagai masyarakat asli yang menempati pulau Kali mantan. Istilah Dayak di dalam masyarakat Kalimantan Barat memiliki berbagai istilah yaitu, Dayak, Daya', dan Dauh yang berarti hulu atau manusia. Namun banyak diantara orang suku Dayak yang menyebut diri mereka Orang Hulu atau Orang Darat atau Orang Pedalaman, selain itu mereka juga menyebut dirinya sebagai Orang Kampung dengan alasan mereka hidup di perkampungan. Menurut Lontaan, J.U (1975:1) Suku Dayak terdiri dalam tujuh rumpun suku dan terdiri dari 405 sub suku dengan bahasa yang berbeda satu dengan lainnya.

Suku Dayak biasanya mendiami daerah pesisir dan sungai-sungai disetiap pemukiman mereka. Sedangkan menurut pendapat Alloy, et.al (2008:78) suku Dayak di Kalimantan Barat memiliki 151 induk suku, diantara beberapa suku tersebut masih dibagi kembali kedalam beberapa suku. Suku-suku tersebut dibagi berdasarkan pada sejarah penyebarannya, wilayah penyebaran, jumlah penutur, bahasa, dan berbagai adat tradisi yang dimiliki. Masing-masing suku Dayak memiliki budaya ada yang berbeda-beda tergantung pada berbagai situasi dan konteks adat tersebut.

Suku dayak terbagi menjadi beberapa rumpun besar, yaitu 1) Apokayan, yang terdiri dari Kenyah, Kayan dan Bahau. 2) Ot Danum-Ngaju terdiri dari Iban, Murut, Klemantandan Punan. Kelompok masyarakat Dayak Punan merupakan suku Dayak tertua yang mendiami pulau Borneo yang berada di Kalimantan dan memiliki adat istiadat dan kebudayaan yang mirip. Oleh karena itu meski terbagi dalam beberapa sub etnis, secara keseluruhan suku Dayak memiliki kesamaan pada budaya dan kebiasaan yang menjadi ciri khas. Melalui ciri khas tersebut dapat menjadi faktor penentu dalam menentukan sub-sub suku di Kalimantan, sehingga dapat digolongkan kedalam beberapa kelompok suku Dayak. Adapun kesamaan yang menjadi ciri khas suku Dayak ialah Rumah Panjang.

Di pulau Kalimantan suku Dayak mendiami seluruh propinsi yang ada, salah satu diantarnya adalah Kalimantan Barat. Kalimantan Barat yang beribukotakan Pontianak dengan luas wilayah $146,807 \mathrm{~km}^{2}$ atau $7,53 \%$ dari luas Indonesia. Menjadi provinsi terluas keempat setelah Papua, Kalimantan Timur dan Kalimantan Tengah. Kalimantan Barat mendapat julukan sebagai provinsi "Seribu Sungai" hal ini sejalan dengan kondisi geografis yang memiliki ratusan sungai besar dan kecil. Sungai menaji urat nadi kehidupan bagi masyarakat di Kalimantan Barat sebagai lintasan yang menjangkau daerah pedalaman, walaupun sarana prasarana jalan darat telah dapat untuk di jangkau.

Dalam kehidupan masyarakat suku Dayak masih berlaku hukum adat bagi siapa saja yang melanggar tanpa terkecuali. Bagi masyarakat suku Dayak mereka percaya akan roh-roh halus serta mahluk gaib yang tinggal ditempat tertentu. Pada umumnya masyarakat Dayak percaya bahwa ada tempat-tempat tertentu yang dipercayai sebagai tempat kediaman mahluk-mahluk halus yang hidup secara berdampingan dengan mereka. Bagi mereka siapapun yang bertindak merugikan atau membawa celaka, serta mereka yang melanggar dan bertindak tidak sesuai dengan aturan adat, akan mendapati pula hukuman yang berlaku sesuai dengan hukum adat suku Dayak. Oleh karena itu masyarakat suku Dayak masih memegang erat kepercayaan Dinamisme atau kepercayaan terhadap benda-benda yang berada disekitar manusia dan meyakini kekuatan gaib yang ada di dalam benda tersebut, sehingga dianggap akan memberikan manfaat bagi kehidupan (Edward, B.T, 1920:160). Masyarakat Dayak percaya bahwa di setiap tempat-tempat tertentu dimiliki oleh penguasa yang biasa disebut dengan Jubata atau Tuhan bagi mereka. Namun pada saat ini banyak diantara mereka lupa akan identitas mereka sebagai suku Dayak dan segala aturan yang ada, ketertarikan mereka pada adat istiadat yang mereka anut selama ini. Menurut pendapat Lontaan (1975:50) pembauran suku Dayak terhadap suku pendatang juga menjadi salah satu faktor terjadinya pergeseran akan keyakinan suku Dayak. Mereka mulai meyakini keyakinan dan memeluk agama pendatang diantaranya agama islam melalui perkawinan dengan suku Melayu. Hal ini dikarenkan suku Malayu identik dengan dengan agama islam sedangkan suku Dayak lebih dikenal dengan Kristiani atau Kepercayaan Dinamisme. 


\section{Budaya Gawai di Kalimantan}

Suku Dayak merupakan salah satu suku yang mengekspresikan kepercayaannya dengan melak sanakan berbagai ritual upacara adat. Bagi suku Dayak ritual-ritual upacara adat memiliki makna tersendiri, hal ini dikarenakan ritual memiliki fungsi dan tujuannya. Salah satu ritual suku Dayak yang rutin dilaksanakan setiap tahunnya ialah Gawai. Gawai adalah salah satu ritual upacara adat yang bertujuan sebagai bentuk ungkapan rasa syukur. Selain itu upacara adat Gawai pada suku Dayak merupakan upacara yang berhubungan dengan lingkungan dan kebiasaan bertani pada masya rakat suku Dayak. Pelaksanaan upacara adat Gawai juga dimanfaatkan sebagai salah satu usaha untuk meningkatkan kecintan masyarakat terhadap kebiasaan-kebiasaan di kalangan suku Dayak yang mulai menurun dikalangan masyarakat suku Dayak di Kalimantan Barat. Masyarakat suku Dayak percaya bahwa dengan melakukan upacara adat dapat membantu mereka dalam melestarikan nilai-nilai budaya Dayak serta yang terpenting ialah ungkapan rasa syukur masyarakat suku Dayak atas hasil panen yang melimpah kepada Tuhan. Gawai juga dapat diartikan sebagai pesta adat yang dilakukan oleh seluruh anggota masyarakat suku Dayak yang masih memegang teguh kepercayaan mereka yaitu Kaharingan. Menurut pendapat Mahim (2009:16) suku Dayak menganut agama Kaharingan. Suku Dayak meyakini bahwa agama tersebut telah ada sejak lama sebelum Hindu, Budha, Islam dan Kristen masuk ke dalam Indonesia. Kaharingan menjadi agama lokal suku Dayak yang dianggap sebagai aliran kepercayaan, sehingga mereka dipandang tanpa memiliki agama. Sebab Kaharingan dianggap sebagai agama suku Dayak yang ada di masa lalu, namun tetap eksis dan masih diyakini oleh sebagian masyarakat suku Dayak sampai saat ini.

Gawai merupakan niatan yang biasa diucapkan oleh orang tua ataupun leluhur. Jika belum dilaksanakan niatan tersebut harus diwariskan kepada anak hingga cucu dan seterusnya hingga niatan tersebut terlaksana. Dalam bentuk tradisional Gawai diartikan sebagai nazar yang merupakan upacara dan hanyas ebatas Nyanga hathn yang berarti pembacaan doa atau mantera. Kemudian dilanjutkan dengan saling mengunjungi antar sesama warga dengan berbagai makanan penyuguh yang khas. Makanan penyuguh seperti kue, lemang, tumpi, bontokng, dan berbagai jenis makanan tradisional lainnya yang terbuat dari hasil panen setiap tahunnya. Upacara adat ini biasa memilliki 18 tahapan dimulai dari Baburukng hingga tahapan terakhir yaitu upacara adat Naik Dango. Sebelum hari $\mathrm{H}$ atau upacara adat Naik Dango dilakukan, masyarakat suku Dayak terlebih dahulu melaksanaan Nyangahathn (pembacaan mantera) yang biasa disebut dengan Matik. Hal tersebut bertujuan untuk memberitahukan dan meminta doa restu kepada Jubata bahwa akan dilaksanakannya pesta adat. Selanjutnya upacara adat dengan pembacaan mantera di lumbung padi (baluh atau langko) bertujuan untuk mengum pulkan dan menambah semangat dan Nyangahathn ditempat beras atau biasa disebut pandarengan. Tujuannya ialah untuk memberkati beras agar dapat bertahan lama dan tidak cepat habis. Oleh karena itu Nyangahathn atau pemba caan mantera merupakan ekspresi atau tata cara utama bagi suku Dayak dalam kegiatan religi.

Menurut Bahari dkk (1996:146) gawai merupakan bentuk upacara religius yang menjadi bagian terpenting dalam setiap upacara dengan tahapan yang baku, dengan tahapan, Matik, Ngalantekatn, Mibis dan Ngadap Buis. Dalam tujuannya Matik bertujuan untuk memberitahukan hajat dan niatan keluarga kepada roh leluhur (awa pama) dan Jubata. Ngalantekatn bertujuan untuk meminta permohonan agar seluruh anggota keluarga diberi keselamatan. Mibis bertujuan untuk membersihkan, melunturkan, menjauhkan dan diterbangkan segala sesuatu dari keluarga dan dikuburkan sebagaimana matahari terbenam pada sore hari kearah barat. Ngadap Buis, merupakan tahapan terakhir yaitu penerimanaan sesajian (buis) oleh Awa Pamadan Jubata. Hal ini bertujuan untuk mengungkapkan rasa syukur atas berkat dan pengudusan (pensucian) terhadap semua hal yang kurang berkenan, termasuk pada saat memanggil seluruh jiwa yang hidup (yang tersesat) agar dapat tenang dan tentram. Oleh karena itu tahapan pertama hingga tahapan ketiga biasa dikenal dengan sebutan Nyangathn mentah yang berarti Nyangahathn dengan bahan mentah atau belum dimasak. Sedangkan Ngadap Buis biasa disebut dengan Nyangatahtn masak, hal ini dikarenakan segala persiapan disiapkan dengan bahan-bahan yang siap dihidang atau sudah masak. Namun jika diartikan secara sederhana Nyangahathn merupakan ungkapan doa pendek dengan sajian sederhana atau biasa disebut dengan Bambang.

Menurut pendapat Rostiyanti (1995:105) upacara adat memiliki fungsi sebagai fungsi spiritual dan fungsi sosial. Fungsi spiritual di dalam upacara adat berfungsi untuk mengatur hubungan manusia dengan Tuhan sedangkan fungsi sosial di dalam upacara adat merupakan segala sesuatu yang mengatur tentang hubungan antar manusia dengan manusia lainnya. Pelaksanaan upacara adat Gawai pada suku Dayak merupakan bentuk aktivitas yang memiliki fungsi sebagai nilai keagamaan, identitas diri atau sebagai interaksi sosial antar sesama masyarakat suku Dayak. Oleh karena itu dapat disimpulkan bahwa upacara adat Gawai memiliki fungsi spiritual ataupun fungsi sosial. Nilai-nilai yang terkandung di dalam kegiatan Gawai memiliki fungi pada nilai keagamaan dan sosial yang terlihat jelas pada saat upacara adat Gawai ini berlangsung. Emosi keagamaan akan menyelimuti para anggota 
upacara yang terlibat langsung pada saat pelaksanaan upacara adat Gawai dilaksanakan. Oleh karena itu upacara adat Gawai biasa digunakan masyarakat suku Dayak sebagai perlindungan spiritual. Hal ini dikarenakan pada saat upacara adat Gawai dilaksanakan seluruh masyarakat suku Dayak terbebas dari rasa bersalah, hutang (nazar) dan kecemasan. Hal ini merupakan salah satu fungsi upacara adat Gawai sebagai fungsi spiritual. Selain itu pada pelaksanaan upacara adat Gawai pada suku Dayak memiliki fungsi sebagai fungsi sosial. Pada upacara adat Gawai juga memberikan sarana komunikasi bagi sesama masyarakat suku Dayak maupun di luar suku Dayak itu sendiri. Sehingga melalui kegiatan tersebut dapat menjadikan satu hubungan sosial antar sesama masyarakat suku Dayak maupun masyarakat diluar suku Dayak. Oleh karena itu upacara adat Gawai menjadi salah satu wadah pemersatu dengan fungsi sebagi media pergaulan antar sesama masyarakat. Untuk melaksanakan kegiatan upacara masyarakat suku Dayak juga memerlukan kerjasama antar sesama untuk bergotong royong. Sehingga terjalin satu bentuk komunikasi dan interaksi di dalam proses tersebut, baik sebelum maupun selama proses pelaksanaan upacara adat Gawai dilaksanakan.

Menurut Situmorang (2004:175) upacara atau ritual merupakan kegiatan yang dilakukan di dalam suatu kelompok atau suku yang dipercayai dan diyakini sebgaian orang tentang spiritual yang dilakukan dengan tujuan tertentu. Pelaksanaan upacara adat Gawai suku Dayak memiliki tujuan untuk meminta kesejahteraan dan keselamatan serta menjaga nilai-nilai kearifan yang terkandung di dalam Gawai sehingga tidak terkontaminasi oleh budaya asing yang banyak berkembang pada era globalisasi pada saat ini. Bagi suku Dayak pelaksanaan upacara adat Gawai merupakan suatu kewajiban sebagai ungkapan rasa syukur kepada Tuhan atau Jubata. Oleh karena itu pelaksanaan upacara Gawai biasa dilaksanakan setelah panen padi selesai yang diikuti oleh seluruh masyarakat suku Dayak. Hal tersebut dilakukan sebagai bentuk ungkapan rasa syukur atas hasil panen padi serta meminta hasil panen selanjutnya semakin baik kepada Tuhan atau Jubata. Selain itu masyarakat juga meminta perlindungan dan dihindarkan dari segala penyakit, diberi kesejahteraan lahir dan batin serta dapat memperkuat sendi-sendi kehidupan, kesejarteraan dan keselamatan bagi seluruh masyarakat. Bagi masyarakat suku Dayak upacara adat Gawai merupakan suatu susunan religi bagi suku Dayak yang ada dikalimantan Barat.

Perayaan Gawai biasa dilaksankan olah suku Dayak pada bulan Mei atau awal Juni. Hal ini dikarenakan perlu banyak persiapan yang dilakukan seperti Ngampar Bide yang berarti menggelar tikar terlebih dahulu yang melibatkan para tokoh suku Dayak, karena mereka akan menjadi penanggung jawab serta memimpin pelaksanaan kegiatan selama upacara dilaksa nakan. Hal tersebut bertujuan agar salama perayaan tersebut berlangsung tidak mendapat kendala dan berjalan lancar. Selain itu upacara gawai juga dilaksanakan di Rumah Bentang Panjang. Menurut Ivo, H (2002:295) hampir seluruh kegiatan gawai dilaksanakan di Rumah Bentang Panjang. Hal ini disebabkan ketika perayaan dilaksanakan suku Dayak berasal dari berbagai daerah bergabung menjadi satu untuk merayakan upacara tersebut di Rumah Bentang Panjang, sebagaimana yang diketahui bahwa Rumah Bentang Panjang memiliki makna tersendiri bagi masyarakat suku Dayak.

Pelaksanaan upacara adat Gawai pada suku Dayak melibatkan banyak pihak. Dimulai dari dana hingga segala persiapan lainnya, hal ini tentunya akan membuat individu-individu dan antar masyarakat satu dengan lainnya saling berinte raksi, melaksanakan musyawarah untuk memutus kan segala sesuatu. Oleh karena itu melalui Gawai dianggap dapat menumbuhkan nilai-nilai solidaritas pada suku Dayak dimana semua pihak yang terlibat pada pelaksanaan Gawai, harus dapat bekerjasama dengan baik untuk mempersiapkan segala kebutuhan dalam pelaksa naan upacara adat Gawai tersebut. Adapun persiapan yang diperlukan pada upacara adat Gawai ialah tahapan persiapan dan tahapan pelaksanaan. Pertama, tahapan persiapan ialah tahapan yang mempersiapkan segala sesuatu bahan yang diperlukan pada pelaksanan Gawai yaitu dengan musyawarah. Musyawarah dilakukan secara tertutup dan rahasia oleh masyarakat suku Dayak hal ini dikarenakan masyarakat suku Dayak menyerahkan kepada kepala adat dalam memu tuskan waktu dan tempat pelaksanaan Gawai tersebut. Kedua, pelaksanaan kedua biasa dilakukan lebih kurang dari 3 minggu sebelum upacara adat Gawai dilaksanakan. Diawali dengan menumbuk padi (beras dan ketan) atau biasa disebut dengan mantuk ase. Pada kegiatan ini membutuhkan waktu yang cukup lama, namun biasanya masyarakat suku Dayak mengerjakan kegiatan ini dengan cara bergotong royong. Mengerahkan semua masyarakat untuk ikut serta sehingga bahu membahu antar satu dengan yang lainnya. Hasil dari kegiatan ini nantinya akan diberikan sama rata kepada seluruh masyarakat yang turut terlibat untuk bergotong royong, adapun hasil yang diberikan biasanya disebut dengan Dung.

Ketiga, selanjutnya biasa dikenal dengan Majejenang Bun yang berarti menghantar atau memberikan undangan kepada seluruh masya rakat suku Dayak, yang berupa gundu atau biasa disebut Bun yang terbuat dari rotan yang dipintal. Keempat, Pandung yang terbuat dari kayu dengan jenis tertentu yang biasa diambil di dalam hutan. Kegiatan ini biasa dilakukan oleh orang-orang tua disuku Dayak. Pandung biasa dibuat untuk diberikan mantera agar setiap mahluk yang 
dikorbankan dalam upacara adat Gawai ini dapat memberikan rezeki dan pahala bagi seluruh masyarakat suku Dayak. Kelima, Bumbulan yaitu acara makan malam yang dilaksanakan selama tiga malam secara berturut-turut dengan tujuan mengingat kembali sejarah cerita Gawai yang dilaksanakan pada hari kelima sebelum upacara adat Gawai dilaksanakan.

Adapun tahapan-tahapan upacara adat Gawai suku Dayak ialah, pertama, Bapipis Mantak merupakan upacara yang diketahui oleh ketua adat untuk membacakan doa dan mantera dengan bahasa Dayak dan dengan berbagai peralatan berupa beras yang diberi minyak goreng (beras banyu). Kedua, Nyangahatn Masak merupakan kegiatan pemotongan ayam lalu dibersihkan dan direbus untuk disajikan dan dipersembahkan kepada Pantak dan Penyungu dengan doa dan mantera yang diketahui oleh ketua adat. Ketiga, Bapinta Bapadah Ka Pantak dan Penyungu. Bapadah memiliki arti pemberitahuan atau memberi tahu kepad Jubata untuk meminta izin akan pelaksanaan Gawai atau pesta adat. Hal tersebut bertujuan untuk meminta keselamatan sehingga di dalam pelaksanaan Gawai diberikan kelancaran dan keselamatan, sehingga alam terhindar dari segala gangguan roh dan mahluk halus. Selanjutnya pelaksanaan persembahan kepada Penyungu, merupakan prosesi adat yang bertujuan sebagai tempat atau lokasi pelaksanaan Gawai dilakukan. Oleh karena itu pada pelak sanaan ini juga diperlukan persembahan yang ditujukan kepada Jubata agar diberikan berkat dan keselamatan. Keempat, Nyapak Umpang, beras kuning dan mantera oleh ketua adat. Pelaksanaan Nyapak Umpang akan dilaksanakan oleh tamu undangan untuk memotong persembahan, sehing ga dapat memberikan potongan terbaik. Menurut kepercayaan suku Dayak potongan terbaik ialah potongan tanpa belulang yang dapat menggam barkan sifat atau kepribadian pemotongnya itu sendiri.

Oleh karena itu dapat disimpulkan bahwa pada pelaksanaan upacara adat Gawai dapat membe rikan dampak pada kehidupan sosial masyarakat suku Dayak di Kalimantan Barat. Gawai sebagai upacara adat yang dilaksanakan secara rutin pada setiap tahunnya. Hal ini tentunya dapat memberikan wadah silaturahmi kepada setiap suku Dayak untuk berkumpul dan bertemu serta bermusyawarah untuk pelaksanaan upacara adat Gawai. Sehingga terjadi interaksi sosial yang dapat berdampak pada rasa persaudaraan yang semakin erat. Selain itu pada pelaksanaan upacara adat Gawai juga menuntut masyarakat untuk saling berkerjasama, saling bahu membahu satu dengan yang lainnya, membentuk sikap kegotong royongan pada suku Dayak itu sendiri. Namun dikarenakan kesakralan pada upacara adat Gawai ini, pada awalnya hanya melibatkan suku Dayak saja tetapi seiring berkembangnya zaman, pada saat ini upacara adat Gawai masuk pada agenda pariwisata di Kota Pontianak yang dilaksanakan satu kali dalam setiap tahunnya. Jadi upacara adat Gawai dapat disaksikan oleh siapa saja masyarakat di luar suku dayak itu sendiri. Bertahannya upacara adat gawai hingga saat ini menjadi bukti bahwa gawai sudah menjadi tradisi bagi masyarakat Dayak di Kalimantan Barat. Gawai menjadi media yang diperlukan untuk menyegarkan rasa solidaritas diantara sesama individu di dalam lingkungan kehidupan bermasya rakat suku Dayak.

\section{Nilai-Nilai Solidaritas}

Solidaritas menurut Zambeta, E. (2014:70) merupakan sebuah konsep dengan konteks keterkaitan individu yang berada di dalam suatu lingkungan rumah, keluarga, kelompok hingga bangsa. Melalui solidaritas individu dapat saling bekerjasama untuk saling mmbantu satu dengan yang lainnya dalam mencapai tujuan tertentu. Kolers, A (2017:12) juga berpendapat bahwa solidaritas merupakan rasa kesamaan yang di dasari kesetaraan yang bertanggung jawab antar individu. Adanya rasa kesatuan yang didasari oleh kepentingan dan rasa persamaan moral dan emosional yang sama sehingga membentuk kelompok individu yang terkait satu dengan lainnya. Oleh sebab itu solidaritas dapat terbentuk dikarenakan adanya tindakan dan tujuan yang sama oleh setiap individu. Hal ini sejalan dengan pendapat Ottman, L.c (2010:23)bahwa solidaritas merupakan suatu keadaan yang terhubung antar individu satu dengan yang lainnya, dengan kelompok satu dengan yang lainnya di dalam masyarakat berdasarkan ikatan perasaan dankeercayaan yang diyakini secara bersamasama. Solidaritas mengarah kepada perasaan saling berbagi, meringankan beban satu dengan yang lainnya. Adapun bentuk-bentuk solidaritas diantaranya ialah gotong royong dan bekerjasama.

Menurut Shadly, H (1993:205) gotong royong merupakan rasa dan tali sosial yang kuat sehingga dapat terjaga di dalam kehidupan bermasyarakat. Gotong royong menjadi kebiasaan pada masyarakat pedesaan dan menjadi bentuk solidaritas di dalam masyarakat. Sedangkan kerjasama merupakan gabungan antar kelompok atau antar individu yang dapat mewujudkan sesuatu yang dihasilkan dan dinikmati secara bersama, sehingga gabungan antar kelompok dan individu dengan individu lainnya disebut dengan badan sosial. Jadi melalui kerjasama tersebut dapat memberikan suatu hal yang bermanfaat bagi masyarakat, menciptakan rasa solidaritas dan nilai-nilai sosial dalam kehidupan bermasyarakat.

Menurut pendapat Alfan (2013:242) nilai sosial merupakan suatu nilai yang dianggap baik dan benar oleh masyarakat sehingga terbentuk berdaasarkan norma dan sanksi sosial di dalam kehidupan masyarakat itu sendiri. Nilai sosial merupakan suatu hal yang dianggap baik, penting dan pantas yang memiliki fungsi bagi 
perkembangan kehidupan di dalam masyarakat. Melalui interaksi individu secara tidak langsung telah melakukan proses sosial sehinggamelalui proses sosialtersebut dapat menciptakan aktivitasaktivitas sosial sebagai proses terbentuknya nilainilai sosial serta solidaritas sosial di dalam kehidupan bermasyarakat. Hal ini sejalan dengan pendapat Enongene M.S (2018:145) bahwa nilai sosial merupakan nilai solidaritas diantara kelompok masyarakat yang berfungsi sebagai pengontrol perilaku masyarakat agar berperilaku sesuai dengan nilai-nilai yang berlaku.

Nilai sosial merupakan segala sesuatu yang berperan penting bagi masyarakat yang dapat mempengaruhi pola dan tata kehidupan bermasyarakat bagi individu-individu sehingga memiliki ruang lingkup yang luas. Menurut Alfan (2013:243-244) nilai sosial terbagi menjadi 3 jenis, yaitu 1) nilai sosial berdasarkan sifat, yaitu nilai kebendaan, nilai kepribadian, nilai biologis, nilai kepatuhan hukum, nilai pengetahuan, nilai keindahan serta nilai agama. 2) nilai sosial berdasarkan cirinya yaitu, nilai dominan yang berarti nilai yang terbentuk berdasarkan lingku ngan sekitar, 3) nilai sosial berdasarkan tingkat keberadaannya yaitu nilai yang dapat berdiri sendiri.

Jadi terkait dengan budaya Gawai pada suku Dayak, nilai-nilai sosial yang dapat membentuk nilai solidaritas terdapat di dalam upacara adat Gawai bagi masyarakat suku Dayak itu sendiri. Upacara adat Gawai memiliki nilai-nilai sosial yang dapat menciptakan nilai solidaritas pada saat upacara adat Gawai tersebut dipersiapkan dan dilaksanakan. Dimana di dalam perencanaan persiapan dan pelaksanaan upacara adat Gawai tersebut, suku Dayak menerapkan sikap dan kebiasaan untuk bermusyawarah, tolong meno long, bahu membahu untuk saling bekerja sama untuk mempersiapkan dan melaksanakan upacara adat Gawai, sehingga memiliki nilai-nilai sosial yang dapat membentuk dan memperkuat nilai solidaritas di dalam kehidupan suku Dayak itu sendiri.

\section{KESIMPULAN}

B erdasarkan dari hasil penelitian yang telah penulis paparkan pada pembahasan sebelumnya, secara umum dapat ditarik kesimpulan bahwa pada Upacara Adat Gawai di Kalimantan Barat dapat membentuk nilai-nilai solidaritas antar masyarakat Suku Dayak. Melalui rangkaian kegiatan upacara Adat Gawai, dimulai dari persiapan hingga pelaksanaan menuntuk masyarakat untuk dapat saling bekerjasama antar satu dengan yang lainnya. Bergotong royong untuk saling bahu membahu mempersiapkan segala kebutuhan dan persiapan selama pelaksanaan upacara Adat Gawai dilaksanakan. Oleh karena itu pada pelaksanaan upacara Adat Gawai ini dapat memberikan dan mempererat nilai-nilai solidaritas pada Suku Dayak. Seiring berkembangnya zaman upacara Adat Gawai pada saat ini juga merupakan salah satu agenda rutin dan menjadi objek wisata di Kota Pontinak yang dapat disaksikan oleh seluruh masyarakat yang ada. Sehingga melalui upacara Adat Gawai dapat menjaga hubungan baik antar suku dayak, lingkungan hingga lingkungan sosialnya dan menumbuhkan rasa kebersamaan setiap individu yang terlibat langsung pada pelaksanaan upacara Adat Gawai.

\section{E. UCAPAN TERIMAKASIH}

$\mathrm{T}$ erimakasih penulis sampaikan kepada bapak Dr. Mukhamad Murdiono, M. Pd. selaku dosen pembimbing yang dengan sabar memberikan bimbingan, masukan, arahan serta dukungan kepada penulis dalam menyusun artikel ini. Terimakasih juga penulis sampaikan kepada Program Pascasarjana Universitas Negeri Yogyakarta yang telah memberi dukungan untuk penerbitan artikel.

\section{DAFTAR PUSTAKA}

Alfan, M. (2013). Pengantar Filsafat Nilai. CV. Pustaka Setia: Bandung

Alloy, L.B, Riskind, J.H, and Maros, M.J. (2004). Stress and Pshysical Disorder :Abnormal Psychology. Edisi 9. New York: Mc GrawHill

Bahri, S. (2015). Dayak Sebagai Sumber Sejarah Lokal Masyarakat Indonesia Sebelum Mengenal Tulisan.Socia. Vol.12, No.2

Carl A. Grant (2018). A better multicultural society: woke citizenship and multicultural activism (DOI: 10.1080/2005615X.2018.1532225)

Edward B. Tylor, (2008). Primitive Culture: Research into the Development of Mythology, Philosophy, Religion, Language, Art and Custom (New York: Brentano's Publishers, t.t.), h. 160

Grant, C.A (2018). A better multicultural society: woke citizenship and multicultural activism. Multicultural Education Review, 1-7. Doi:10.10802005615x.2018.1532225

Hatu, R. (2011). Perubahan Sosial Kultural Masyarakat Pedesaan. Jurnal Inovasi Vol. 8 No. 4 h. 111

158 | P a g e

https://doi.org/10.25077/jantro.v22.n2.p151-159.2020

IRMALINI SYAFRITA, MUKHAMAD MURDIONO 
Ivo, H. (2002). "Upacara adat perladangan Dayak Kanayatn, Kalimantan Barat". Laporan penelitian.Fakultas Keguruan dan Ilmu Pendidikan. Pontianak: Universitas Tanjungpura.

Ivo, H. (2001). Gawai Dayak Dan Fanatisme Rumah Panjang Sebagai Penelusuran Identitas. Journal Article Humaniora. Doi:10.22146/Jh.V13i3.736

Kolers, A. (2017). Solidarity as environmental justice in brownfields remediation:Critical Review of International Social and Political Philosophy, 1-16. DOI: 10.1080/13698230.2017.1398857

Lontaan, J.U. (1975), Sejarah Hukum Adat dan Adat Istiadat Kalimantan Barat. Offset Bumi Restu, Pemda Kalimantan Barat.

Mahin, M. (2009). Dinamika Agama Dayak di Kalimantan Tengah. Jakarta: Departemen Pendidikan dan Kebudayaan

Ottmann, J. (2010). Social Exclusion In The Welfare State: The Implications Of Welfare Reforms For Social Solidarity And Social Citizenship. Distinktion. Journal of Social Theory, 11(1), 23-37. doi:10.1080/1600910x.2010.9672753

Setiadi, E. M. \& Kolip, U. (2011). Pengantar Sosiologi Pemahaman Fakta dan Gejala Permasalahan Sosial : Teori, Aplikasi, dan Pemecahnya. Jakarta: Kencana

Shadily, H. (1993). Sosiologi untuk Masyarakat Indonesia. Jakarta: PT. Rineka Cipta.

Siebold, A. (2017). Open Borders As An Act Of Solidarity Among Peoples, Between States Or With Migrants: Changing Applications Of Solidarity Within The Schengen Process. Doi.org/10.1080/13507486.2017.1345862

Situmorang, S. (2004). Toba Na Sae; Sejarah Lembaga Sosial Politik Abad XIII-XX. Jakarta: Komunitas Bambu

Sone, E. M. (2018). The Folktale and Social Values in Traditional Africa: Eastern African Literary and Cultural Studies, 4(2), 142-159.doi:10.1080/23277408.2018.1485314

Supardan, D. (2013). Pengantar Ilmu Sosial Sebuah Kajian Pendekatan Struktural. Jakarta: PT Bumi Aksara.

Tormos, F. (2017). Intersectional solidarity. Politics, Groups, and Identities, 5(4), 707720. doi:10.1080/21565503.2017.1385494

Rostiyanti, A. (1995). Fungsi Upacara Tradisional Bagi Masyarakat Pendukungnya Masa Kini. Yogyakarta: Departemen Pendidikandan Kebudayaan.

Purwanto, Y. \& Soedjito, H. (2009).Studi Etnologi Masyarakat Dayak Kenyah Uma' Lung di Kalimantan Utara.

Vitany,I.(2015). Tradition and Modernit :World Futures, 34(3-4), 253-255. Doi: 10.108002604027.1992.9972312

Zambeta, E. (2014). Education and Social Solidarity in times of Crisis: the case of voluntary shadow education in Greece. Education Inquiry, 5(1), 24058. doi:10.3402/edui.v5.24058

Zed, M. (2008).Metode Penelitian Kepustakaan. Jakarta: Yayasan Obor Indonesia 